\title{
Strategi ekspansi usaha dan pengelolaan kas berbasis teknologi informasi pada era new normal
}

\author{
Fidiana Fidiana ${ }^{\star *}$, Widhi Ariestianti ${ }^{2}$, Endang Dwi Retnani ${ }^{3}$, Dini \\ Widyawati ${ }^{4}$
}

\begin{abstract}
1Sekolah Tinggi IImu Ekonomi Indonesia Surabaya, Indonesia, email: fidiana@stiesia.ac.id
2Sekolah Tinggi IImu Ekonomi Indonesia Surabaya, Indonesia, email: widhiariestianti@stiesia.ac.id

${ }^{3}$ Sekolah Tinggi IImu Ekonomi Indonesia Surabaya, Indonesia, email: endangdwiretnani@stiesia.ac.id

${ }^{4}$ Sekolah Tinggi IImu Ekonomi Indonesia Surabaya, Indonesia, email: diniwidyawati@stiesia.ac.id

*Koresponden penulis
\end{abstract}

\section{Info Artikel}

Diajukan: 22 Jan 2021

Diterima: 12 Jun 2021

Diterbitkan: 18 Jun 2021

Keywords:

sme; sukolilo; business strategy; cash management

Kata Kunci:

umkm; sukolilo; strategi

usaha; pengelolaan kas

\section{Lisensi: \\ cc-by-sa}

\begin{abstract}
Handicraft SMEs are one of the sectors affected by the Covid-19 pandemic. The implementation of this community service activity aims to offer the right expansion strategy for MSMEs affected by the Covid19 pandemic. The scope of community service activities is limited to the Sukolilo Surabaya Handicraft SMEs. Some MSMEs have managed to survive and some have been less fortunate. The method of activity is to provide recommendations through virtual assistance activities through zoom and WhatsApp social media related to strategies to increase business and manage finances during the new normal era. The results of this community service activity include several MSMEs responding by diversifying their products and businesses. Second, partners with marketing problems have created accounts through the Instagram and Facebook applications and have participated in the exhibition agenda. Third, partners with financial problems have carried out simple financial management manually and using the SME Accounting application.
\end{abstract}

Abstrak
UMKM handycraft merupakan salah satu sektor yang terdampak
pandemi Covid-19. Pelaksanaan kegiatan pengabdian kepada
masyarakat ini bertujuan untuk menawarkan strategi ekspansi yang
tepat bagi UMKM yang terdampak pandemi Covid-19. Ruang lingkup
kegiatan pengabdian kepada masyarakat terbatas pada UMKM
handycraft Sukolilo Surabaya. Beberapa UMKM ada yang berhasil
bertahan dan beberapa lainnya kurang beruntung. Metode kegiatan
adalah adalah memberikan rekomendasi melalui aktivitas
pendampingan secara virtual melalui zoom dan media sosial
whatsapp berkaitan dengan strategi meningkatkan usaha dan
mengelola keuangan selama era new normal. Hasil dari kegiatan
pengabdian kepada masyarakat ini antara lain beberapa UMKM
merespon dengan mendiversifikasi produk dan usahnya. Kedua, mitra
dengan masalah pemasaran telah dibuatkan akun melalui aplikasi
instagram dan facebook serta telah berpartisipasi pada agenda
pameran. Ketiga, mitra dengan masalah keuangan telah melakukan
pengelolaan keuangan sederhana dengan cara manual dan
memanfaatkan aplikasi Akuntansi UKM.




\section{PENDAHULUAN}

Pandemi diakui mengubah drastis seluruh tatanan ekonomi, bisnis, sosial (Ratten, 2020a), pendidikan, agama, dan kemasyarakatan (Donthu \& Gustafsson, 2020). Pola-pola bermasyarakat, berekonomi, beragama, konsumsi, dan aspek lainnya berubah total dari berbasis tatap muka menjadi berpola virtual. Ada banyak jenis bisnis yang terhenti tiba-tiba sehingga memaksa banyak pemutusan kerja, namun di sisi lainnya kita melihat pertumbuhan bisnis berbasis virtual yang luar biasa.

Pandemi memang berhasil mengubah tatanan dan gaya hidup dan menantang inovasi di banyak aspek. Varian aktivitas dan usaha baru bermunculan dan berkembang, tak terkecuali adalah bermunculannya usaha makanan rumahan siap antar. Banyak UMKM yang mengubah orientasi bisnisnya menjadi fokus pada penyediaan makanan dan minuman, jasa antar (Ombi et al., 2018), hiburan, tanaman, serta peralatan olahraga (Ratten, 2020b) seperti sepeda lipat. Harus diakui bahwa bisnis saat ini sudah bergerak ke sektor jasa, hiburan, dan olahraga. Perubahan ini mendorong dan memaksa UMKM untuk mampu bersaing secara online.

Cara-cara pemasaran produk selama pandemi juga sudah beralih menjadi berbasis pemasaran digital (Junusi, 2020). Sementara itu, tidak semua pelaku UMKM mampu dengan cepat mengadaptasi perubahan digital. Disadari bahwa secara umum kemampuan UMKM merespon teknologi digital cukup rendah sehingga membutuhkan pendampingan dari perguruan tinggi sebagai mitra masyarakat. Perubahan skala bisnis berdampak pada perubahan keuangan. Pola pengelolaan kas dengan demikian juga dibutuhkan UMKM untuk menyesuaikan dengan kondisi sistem keuangan virtual (Ernest, 2018).

Salah satu UMKM yang berusaha bertahan di tengah situasi pendemi adalah UMKM handy craft di kecamatan Sukolilo. Aktivitas bisnis handycraft terhenti selama pandemi. Sebagaimana diketahui bahwa usaha handycraft berkaitan erat dengan industri pariwisata (Sahara et al., 2016). Ini berarti, keberlangsungan bisnis handycraft sangat tergantung pada industri pariwisata. Terhentinya bisnis pariwisata selama pandemi covid-19 menghentikan bisnis handycraft.

Pandemi mendorong beberapa pelaku UMKM Sukolilo mengalihkan bisnisnya pada bidang lainnya seperti bisnis makanan, minuman herbal, masker, dan barang-barang kebutuhan pokok lainnya. UMKM yang lain yang sebelumnya memproduksi tas, beralih memproduksi kerajinan lainnya seperti payung. Hal ini merupakan semangat UMKM merespon tema-tema ekonomi pemerintah daerah yang digulirkan selama musim pandemi. Peralihan usaha ini diharapkan dapat menunjang kelangsungan ekonomi UMKM.

Peralihan bisnis bukan hal yang mudah bagi UMKM terutama pada aspek menjangkau pasar lokal dan pasar yang lebih luas. Bagi pengusaha payung misalnya, aspek produksi bukan masalah substansial, karena umumnya banyak pendampingan dan pembinaan dari pemerintah setempat. Masalah utama UMKM umumnya berkaitan dengan pemasaran dan daya serap pasar terhadap produk. 
Berdasarkan fenomena di atas, perlu bagi UMKM untuk terus meningkatkan skill pengelolaan bisnis dengan memanfaatkan fasilitas digital terutama pada aspek pemasaran termasuk pengelolaan keuangan. Media digital dan online akan meningkatkan kapabilitas diferensiasi usaha UMKM sehingga mampu bersaing dengan lawan bisnisnya. Kegiatan ini dimaksudkan untuk memberikan pendampingan terkait strategi diferensiasi usaha dan peningkatan kapabilitas UMKM dalam pengelolaan bisnis (pemasaran dan keuangan). Jadi, tulisan ini bertujuan menyajikan strategi diferensiasi usaha dan peningkatan kapabilitas UMKM dalam pengelolaan bisnis (pemasaran dan keuangan) dengan memanfaatkan media digital (online).

\section{METODE PELAKSANAAN}

Metode yang digunakan dalam kegiatan ini adalah pendampingan terkait strategi diferensiasi usaha dan peningkatan kapabilitas UMKM dalam pengelolaan bisnis (pemasaran dan keuangan). Protokol kesehatan selama pandemi covid-19 tetap menjadi perhatian utama, sehingga pendampingan dilaksanakan secara virtual melalui media sosial yang tersedia (zoom). Interaksi intensif dilakukan dengan membuat grup whatsapp.

Selain pendampingan secara virtual, beberapa agenda yang mengharuskan tatap muka seperti misalnya partisipasi pada festival UMKM juga dilakukan di beberapa kegiatan. Proses pendampingan juga melibatkan mahasiswa yang dibagi menjadi beberapa kelompok sehingga kegiatan pendampingan lebih terorganisir. Mahasiswa berperan melakukan monitoring aktivitas teknis yang dibutuhkan pelaku UMKM seperti membuatkan akunakun di media sosial serta kebutuhan pengelolaan kas harian untuk menjaga stabilitas arus kas selama pandemi. Tim pengabdi memandang bahwa pendampingan tidak boleh terhenti karena situasi pandemi.

Secara teknis, langkah-langkah yang dilakukan tim pelaksana adalah pertama pemetaan masalah utama UMKM. Dari hasil pemetaan, UMKM kemudian dikelompokkan menjadi 3 (tiga) klaster yaitu berdasarkan masalah diferensiasi usaha, masalah pemasaran dan daya serap pasar, masalah pengelolaan bisnis dan keuangan. Kedua, kegiatan pendampingan diklasterisasi menjadi 3 bagian sehingga fokus pada tiga hal sebagaimana disampaikan pada poin pertama. Setiap klaster didampingi oleh tim pengabdi (1-2 dosen dan 2 mahasiswa).

Kegiatan pendampingan dilakukan dengan memberikan rekomendasi solusi sesuai dengan masalah mitra. Bagi mitra dengan kendala kebuntuan usaha diberi rekomendasi diferensiasi, mita dengan kendala pemasaran dan daya serap pasar, diatasi melalui pembuatan akun pada aplikasi instagram dan facebook (tergantung kesediaan mitra) dan pengisian konten produk. Bagi mitra dengan masalah pengelolaan keuangan, tim pengabdi mengenalkan aplikasi pengelolaan keuangan sederhana baik melalui kertas kerja manual maupun pemanfaatan aplikasi Akuntansi UKM yang tersedia di telepon seluler. Ketiga, monitoring dan evaluasi atas kegiatan pendampingan dilakukan secara mingguan dan bulanan serta pada akhir bulan ke-enam. 
Monitoring dan evaluasi dilaksanakan secara virtual dengan komunikasi melalui media sosial.

\section{HASIL DAN PEMBAHASAN}

Berdasarkan hasil interaksi dengan pelaku UMKM yang mengeluhkan lumpuhnya bisnis mereka, yang mana terutama karena bisnis kerajinan tangan memang bukan kebutuhan pokok selama pandemi. Beberapa saran untuk melakukan diferensiasi usaha disambut dengan baik. Ekspansi bisnis memang dibutuhkan selama pandemi (Komara et al., 2020).

Beberapa pelaku UMKM bersedia mencoba beralih bisnis. Orientasi kebutuhan konsumsi saat ini masih fokus pada kebutuhan pokok atau primer seperti makanan dan kesehatan yang berguna untuk memproteksi diri dari infeksi virus. Kebutuhan hiburan untuk menyeimbangkan atau menjaga tingkat stress untuk tidak terlalu tinggi yang berakibat pada menurunnya imunitas tubuh sehingga dapat mengganngu produktifitas kerja.

Ekspansi usaha antara lain dilakukan oleh Ibu Rima. Saat pandemi ini $\mathrm{Bu}$ Rima memproduksi menjual bros dan connector masker. Sebelum pandemi, Bu Rima menjalankan usaha dagang jilbab dan baju gamis. Selain bros dan connector masker, Bu Rima juga menjual aneka makanan pada sore hari seperti dorayaki, sempol, cireng, telur sosis, es lilin, es gabu dan wedang pokak. Bu Rima juga membantu suaminya berjualan barang kebutuhan pokok seperti beras dan telur. Semua kegiatan pemasaran produk dilakukan secara online melalui whatsapp begitu juga pemesanan atas produk yang dilakukan. Selain itu, bu Rima juga menitipkan barang dagangan pada sentra UMKM Magrove, sehingga daya jualnya menjadi lebih luas.

Selain bu Rima, peragaman usaha juga dilakukan oleh bu Ermin. Semula, Bu Ermin memproduksi aneka kerajinan tas yang dibuat dari bungkus semen. Kerajinan tas Bu Ermin memiliki ciri khas dengan teknik jumputan. Produk tas Bu Ermin telah terkenal bahkan hingga ekspor ke berbagai negara. Selama pandemi, produksi tas Bu Ermin terhenti akibat lesunya bidang pariwisata. Hal ini dikarenakan bahwa teknik pemasaran Bu Ermin selama ini banyak bekerja sama dengan kapal pesiar. Setelah diskusi dan interaksi, Bu Ermin memutuskan beralih memproduksi payung ecoprint.

Payung ini dibuat dari bahan baku bungkus semen. Ide ini dimulai dari menangkap peluang festival payung yang diselenggarakan tahun 2020 . Contoh produk payung ecoprint tampak pada gambar 1 . 


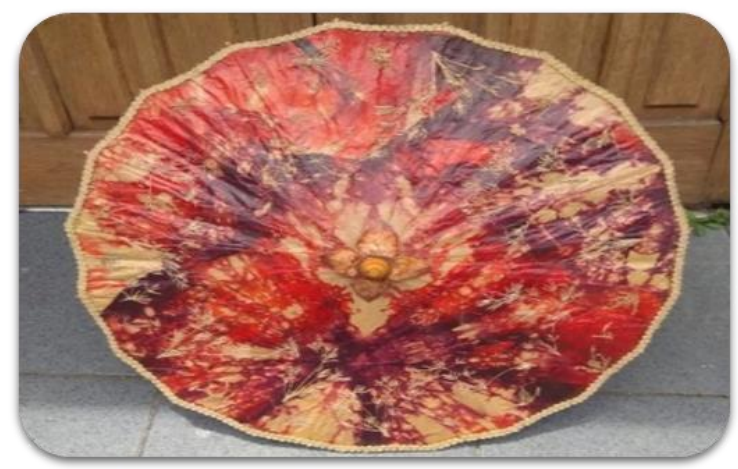

Gambar 1. Contoh Koleksi Produk Payung Ecoprint

Produk payung ecoprint Bu Ermin banyak disukai masyarakat terutama pencinta seni. Banyak UMKM tertarik belajar membuat payung ini ke Bu Ermin melalui media whatsapp. Peluang ini tidak disia-siakan. Bu Ermin membuka kelas-kelas workshop pembuatan ecoprint di kediamannya. Untuk kepentingan belajar, tidak menggunakan kertas sak semen tetapi pada kertas biasa.

Upaya Bu Ermin dalam memberikan pelatihan teknis ecoprint meluas tanpa diduga. Kabupaten Bojonegoro bahkan mengundang Bu Ermin untuk memberikan pelatihan kerajinan ecoprint. Pada kegiatan ini, Bu Ermin memberikan pelatihan pembuatan dompet kertas ecoprint. Rekaman kegiatan pelatihan dapat dilihat pada Gambar 2. Hal ini menunjukkan ada kepedulian dan keberpihakan pemerintah dalam menunjang perkembangan UMKM di tanah air (Wahab, 2016; Winarno, 2012).

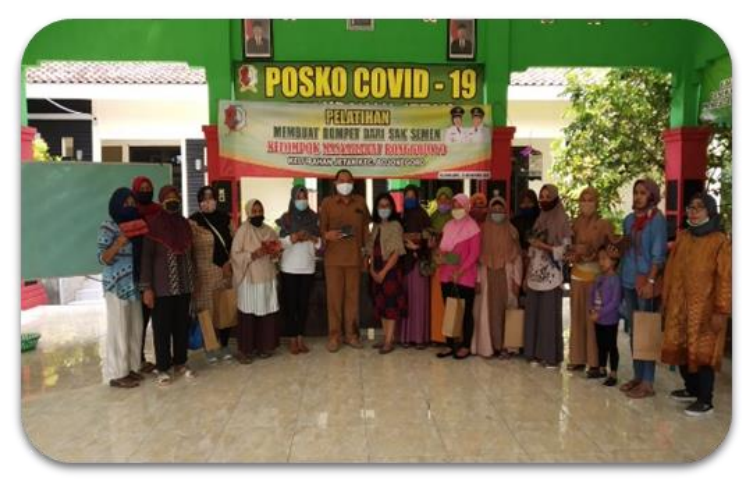

Gambar 2. Pelatihan Pembuatan Payung Ecoprint

Sementara itu, kerajinan payung ecoprint juga menjadi perhatian masyarakat. Padahal, harga kerajinan payung kertas ecoprint ini tergolong tidak murah, yaitu antara Rp. 500.000 - Rp. 1.500 .000 per payung. Daya tarik kerajinan payung kertas ecoprint ini dimanfaatkan oleh Bu Ermin untuk memperluas jejaring. Salah satu upayanya adalah mengikuti Festival Payung Nusantara 2020. Kegiatan festival payung ini diselenggarakan pada tanggal 4- 
6 Desember 2020. Keikutsertaan pada festival ini tentu dimaksudkan untuk meningkatkan jejaring pemasaran (Wulandari \& Parameswara, 2020).

Peserta yang ingin hadir pada festival payung ini wajib mem-follow akun instagram dan mengirimkan bukti scree shoot ke panitia penyelenggara seminar. Partisipasi Bu Ermin pada festival payung ini meningkatkan pangsa pasar dan mendapatkan kesempatan untuk memperkenalkan produknya kepada masyarakat.

Pada festival ini, Bu Ermin juga dipercaya menjadi salah satu narasumber pada kelas ecoprint kertas, pada tanggal 5 Desember 2020. Interaksi kelas dan bertukar ilmu dengan narasumber lainnya ternyata juga menambah wawasan $\mathrm{Bu}$ Ermin yang berguna untuk meningkatkan pengetahuan dan skill (Fahmi et al., 2020) untuk menghasilkan aneka kerajinan.

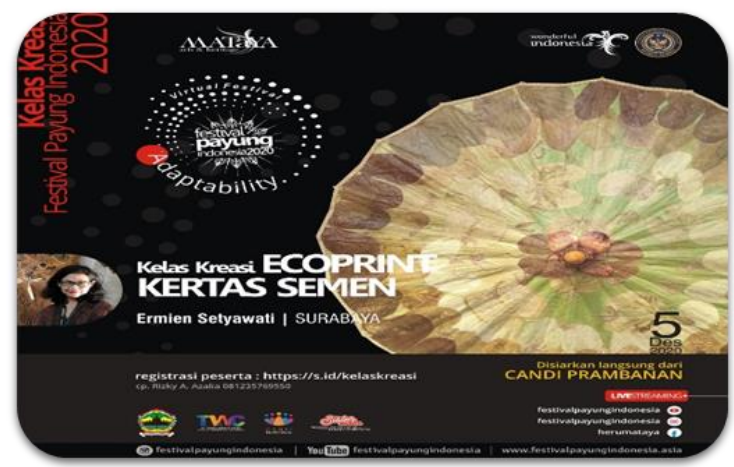

Gambar 3. Partisipasi pada Festival Payung 2020

Aktivitas pendampingan pengelolaan kas dilaksanakan secara online dengan interaksi melalui media whatsapp. Ibu-lbu pelaku UMKM cukup semangat dan disiplin dalam menerapkan pengelolaan keuangan melalui kertas kerja sederhana. Bukti-bukti dikumpulkan dan dicatat pada buku secara manual, kemudian ditunjukkan dengan cara capture dan di-share ke whatsapp mahasiswa dan kemudian dilaporkan ke tim Dosen. Sementara itu, bagi mitra yang menggunakan aplikasi Akuntansi UKM, dalam penggunaannya didampingi (dipandu) oleh mahasiswa.

\section{KESIMPULAN}

UMKM handycraft Kecamatan Sukolilo telah melakukan berbagai upaya bisnis sesuai dengan kegiatan pendampingan, yaitu diferensiasi usaha, pengembangan aktivitas pemasaran melalui pembuatan akun dan keterlibatan pada pameran produk yang diselenggarakan pemerintah, serta pemanfaatan pengelolaan keuangan secara sederhana dan berbasis aplikasi telepon seluler.

Meskipun sulit namun upaya difersifikasi atas usaha yang dijalankan merupakan solusi yang dipilih oleh UMKM Kecamatan Sukolilo dalam bertahan di tenagh situasi yang sulit. Pemanfaatan media digital berbasis 
aplikasi memang tidak mudah dilaksanakan karena butuh dibiasakan. Keterbatasan sumber daya pemanfaatan media digital ini dapat diatasi dengan pendampingan oleh mahasiswa secara aktif dan intensif.

Saran yang dapat diberikan adalah bahwa difersifikasi usaha lebih baik dilakukan pada bisnis yang menyajikan kebutuhan pokok harian. Literasi penggunaan teknologi informasi harus ditingkatkan untuk terus meningkatkan usaha yang dijalankan dikarenakan adanya perubahan pola konsumen dalam mengambil keputusan pembelian. Media sosial merupakan hal yang wajib dipelajari dan dikuasai oleh seluruh pelaku UMKM.

\section{UCAPAN TERIMA KASIH}

Ucapan terima kasih disampaikan kepada STIESIA Surabaya atas kesempatan untuk melakukan kegiatan pengabdian kepada masyarakat dan juga kepada Kecamatan Sukolilo yang memberikan kepercayaan kepada tim pengabdi untuk menjadi pendamping dalam mengembangkan aktivitas UMKM handycraft.

\section{DAFTAR RUJUKAN}

Donthu, N., \& Gustafsson, A. (2020). Effects of COVID-19 on business and research. Journal of Business Research, 117, 284-289. https://doi.org/10.1016/j.jbusres.2020.06.008

Ernest, N. (2018). The Role of Bookkeeping on the Survival of Very Small Businesses in the Kumba Municipality. International Journal of Advanced Engineering, Management and Science, 4(10), 713-723. https://doi.org/10.22161/ijaems.4.10.1

Fahmi, A. R., Hadiyati, E., \& Ahmad, A. (2020). Pengaruh Knowledge dan Skill Terhadap Kinerja melalui Kompetensi Kewirausahaan pada Pengusaha UKM Produk Unggulan Kota Malang. REFORMASI, 10(1), 1-10. https://doi.org/10.33366/rfr.v10i1.1596

Junusi, R. El. (2020). Digital Marketing During the Pandemic Period; A Study of Islamic Perspective. Journal of Digital Marketing and Halal Industry, 2(1), 15-28. https://doi.org/10.21580/jdmhi.2020.2.1.5717

Komara, B. D., Setiawan, H. C. B., \& Kurniawan, A. (2020). Jalan Terjal UMKM dan Pedagang Kecil Bertahan di Tengah Pandemi Covid-19 dan Ancaman Krisis Ekonomi Global. Jurnal Manajemen Bisnis, 17(3), 342-359. https://doi.org/10.38043/jmb.v17i3.2506

Ombi, N., Ambad, S. N. A., \& Bujang, I. (2018). The Effect of Business Development Services on Small Medium Enterprises (SMEs) Performance. International Journal of Academic Research in Business and Social Sciences, 8(3), 117-130. https://doi.org/10.6007/IJARBSS/v8-i3/3910

Ratten, V. (2020a). Coronavirus (covid-19) and social value co-creation. International Journal of Sociology and Social Policy, ahead-of-p(aheadof-print). https://doi.org/10.1108/IJSSP-06-2020-0237

Ratten, V. (2020b). Coronavirus disease (COVID-19) and sport entrepreneurship. International Journal of Entrepreneurial Behavior \& 
Research, 26(6), 1379-1388. https://doi.org/10.1108/IJEBR-06-20200387

Sahara, F. N. A., Iqbal, M., \& Sanawiri, B. (2016). Analisis Motivasi Berkunjung Wisatawan dan Tingkat Pengetahuan Wisatawan tentang Produk Industri Kreatif Sektor Kerajinan (Studi Pada Wisatawan Domestik di Kota Batu, Jawa Timur). Jurnal Administrasi Bisnis, 35(2), 146-154.

http://administrasibisnis.studentjournal.ub.ac.id/index.php/jab/article/vie $\mathrm{w} / 1380$

Wahab, A. (2016). Keberpihakan Kebijakan Pemerintah pada Sektor Usaha Rakyat Perspektif Ekonomi Islam (Studi Kasus Keberlangsungan Pasar Tradisional). TSAQAFAH, 12(1), 167-186. https://doi.org/10.21111/tsaqafah.v12i1.373

Winarno, B. (2012). Kebijakan Publik: Teori, Proses, dan Studi Kasus. PT. Buku Seru.

Wulandari, I. G. A. A., \& Parameswara, A. A. G. A. (2020). Problematika UMKM Berbasis Budaya Lokal di Bali (Studi Kasus Pemasaran Produk UMKM Berbasis Budaya Lokal di Pesta Kesenian Bali). Ekonomi Dan Bisnis, 6(2), 101-120. https://doi.org/10.35590/jeb.v6i2.1263 